\title{
Implementasi Aplikasi Perpustakaan Online Pada Sekolah Menengah Kejuruan Berbasis Model UML
}

\author{
Adika May Sari", Desri Yani \\ Teknologi Informasi, Sistem Informasi, Universitas Bina Sarana Informatika, Jakarta, Indonesia \\ Email: 1,*adika.dik@bsi.ac.id, ${ }^{2}$ desri.dsr@bsi.ac.id
}

\begin{abstract}
Abstrak
Implementasi Sistem pendataan peminjaman buku yang sudah terkomputerisasi dapat berjalan lebih baik dan efisien dari sistem manual, serta bisa meminimalisir pengunaan kertas. Sistem pendataan yang dilakukan seperti transaksi peminjaman dan pengembalian buku yang masih dilakukan secara manual yaitu dengan mencatat transakasi peminjaman dan pengembalian di dalam buku. Metode pencatatan manual seperti ini dianggap kurang efektif dan efisien, dikarenakan dapat menyita waktu dan tenaga petugas perpustakaan dalam hal mendata secara manual. Oleh karena itu dengan adanya komputer dan internet, dengan membuat sebuah aplikasi perpustakaan online maka akan mampu memberikan pelayanan yang memuaskan bagi para siswanya dan membantu petugas perpustakaan dalam memproses pendataan buku. Melalui sistem pendataan yang sudah terkomputerisasi seperti membangun sebuah website aplikasi perpustaakn online, dapat membantu petugas perpustakaan dalam proses pendataan dan pembuatan laporan yang lebih efektif dan efisien, serta dapat memudahkan siswa yang ingin mencari buku dan meminjam buku di perpustakaan menjadi lebih mudah. Maka implementasi website aplikasi perpustaakn online adalah solusi yang baik untuk mempermudah mengatasi masalah tersebut. Di dalam penelitian ini dibuat sebuah website untuk melakukan transaksi peminjaman dan pendataan buku di perpustaakaan, lalu dibuatkan search engine (mesin pencari) yang memudahkan user menjadi buku sesuai dengan judul . Implementasi ini menggunakan metode UML ( unified Modelling Language ), dimana didalam metode UML akan dibuat class diagram, use case diagram, activity diagram, untuk menjelaskan behavior (perilaku) dari sistem yang akan digunakan pada aplikasi perpustakaan. yang fungsinya dapat menghasilkan website yang baik.
\end{abstract}

Kata Kunci: Perpustaakaan; Online; Buku; Transaksi

\section{Abstract}

Implementation of a computerized book lending data collection system can run better and more efficiently than manual systems, and can minimize paper usage. Data collection systems such as borrowing and returning books are still done manually, namely by recording borrowing and returning transactions in the book. Manual recording method like this is considered less effective and efficient, because it can consume time and librarian personnel in terms of manual data collection. Therefore, with computers and the internet, by making an online library application it will be able to provide satisfying services for students and assist librarians in processing book data collection. Through a computerized data collection system such as building an online library application website, it can help librarians in the process of collecting data and making reports that are more effective and efficient, and can make it easier for students who want to find books and borrow books in the library more easily. So the implementation of the online library application website is a good solution to make it easier to solve this problem. In this study, a website was created to carry out borrowing transactions and book data collection in the library, then a search engine was created which made it easy for users to become books according to the title. This implementation uses the UML (unified Modeling Language) method, where the UML method will create class diagrams, use case diagrams, activity diagrams, to explain the behavior of the system to be used in library applications. whose function can produce a good website.

Keywords: Library; Online; Books; Transactions

\section{PENDAHULUAN}

Perkembangan teknologi informasi yang semakin canggih menimbulkan dampak atau perubahan yang sangat signifikan pada dunia teknologi, sehingga melahirkan berbagai macam teknologi digital yang kemudian sering disebut sebagai era digital. Era digital muncul dengan memanfaatkan teknologi informasi komputer yaitu dengan menggunakan internet [1], [2]. Perpustakaan adalah suatu ruangan yang dikelola oleh lembaga pendidikan yang digunakan untuk sarana tempat belajar yang menyediakan berbagai macam koleksi buku. Sekolah merupakan bangunan atau lembaga untuk sarana dan prasarana belajar dan mengajar serta tempat bagi murid-murid untuk menerima dan memberi pelajaran. Untuk mewujudkan perpustakaan yang terorganisasi secara baik dan sistematis. Maka perpustakaan harus mempunyai aplikasi perpustakaan berbasis web, yang dapat memberikan kemudahan bagi proses peminjaman atau pencarian buku di perpustakaan sekolah tersebut [3].

Perpustakaan berkembang dengan pesat dan dinamis, sistem manualnya dirasakan tidak lagi memadai untuk penanganan beban kerja, khususnya kegiatan rutin dalam bidang pengadaan, pengatalogan, dan pengawasan sirkulasi. Keadaan demikian menuntut penggunaan sistem informasi berbasis teknologi komputer atau CBIS (Computer Base Information System)[4]. Perpustakaan SMK (Sekolah Menengah Kejuruan) sudah memiliki berbagai koleksi buku, baik buku yang terkait dengan pelajaran sekolah maupun buku-buku yang tidak terkait dengan pelajaran sekolah. Akan tetapi proses pengolahan data pada perpustakaan SMK saat ini masih menggunakan cara yang konvensional, yakni mencatat data anggota, data buku, data peminjam, data pengembalian, dan denda keterlambatan pengembalian buku ke dalam sebuah pembukuan. Petugas Perpustakaan SMK mempunyai masalah dalam proses pengolahan data, seperti ketika mencari data peminjam dalam 
pembukuan, selain itu petugas juga kesulitan untuk mengetahui ketersediaan buku, karena harus mengecek satupersatu dalam rak buku.

Siswa yang akan meminjam atau mengembalikan buku membutuhkan waktu yang cukup lama, karena harus menunggu petugas mencatat buku yang dipinjam dalam pembukuan. Siswa juga harus menunggu lama ketika akan mengembalikan buku, karena petugas harus mencari data peminjam satu persatu dalam pembukuan. Masalah lain yang ada di perpustakaan SMK adalah siswa mengalami kesulitan dalam pencarian buku yang akan di pinjam jika harus mencari buku tersebut di rak sedangkan informasi buku tersebut tidak di informasikan statusnya apakah buku tersebut masih ada atau sedang dipinjam, padahal informasi dari perpustakaan dibutuhkan oleh siswa untuk mengetahui informasi koleksi buku dan hal lain yang ada di perpustakaan SMK.

Fungsi Perpustakaan sekolah sebagai tempat baca yang sekarang semakin kurang diminati oleh siswa untuk membaca buku dan mencari literatur ilmu pengetahuan, hal ini desebabkan karena terkalahkan oleh media informasi seperti internet yang lebih mudah digunakan dalam pencarian berbagai macam ilmu dan sumber bacaan. Dampak media informasi tersebut juga dialami oleh Perpustakaan SMP Negeri 1 Donorojo yang banyak memiliki koleksi buku yang seharusya bisa digunakan oleh para siswa untuk menunjang kegiatan belajar namun siswa kurang tertarik untuk membaca dan meminjam buku dari perpustakaan tersebut selain ada tugas tertentu dari guru yang mengharuskan siswa meminjam buku dari perpustakaan [5].

Berdasarkan latar belakang tersebut maka perumusan masalah yang dapat diambil dalam penelitian ini adalah membangun aplikasi administrasi perpustakaan berbasis web SMK dengan menggunakan bahasa pemrograman web , yaitu menggunakan PHP dan My SQL, dengan menggunakan metode UML, dimana metode UML berguna untuk memodelkan suatu sistem (bukan hanya perangkat lunak) yang menggunakan konsep berorientasi object. Dan juga untuk menciptakan suatu bahasa pemodelan yang dapat digunakan baik oleh manusia maupun mesin.

Agar lebih rinci dan sesuai dengan kebutuhan perpustakaan, maka dirancang suatu sistem pengolahan data perpustakaan seperti data anggota, data buku, data pengarang, data penerbit, data pegawai, tabel peminjaman buku dan tabel engembalian buku. Tujuan dari aplikasi perpustakaan ini adalah meningkatkan efisiensi kerja perpustakaan yang semula menggunakan sistem manual menjadi sistem informasi berbasis teknologi komputer atau CBIS (Computer Base Information System).

\section{METODE PENELITIAN}

\subsection{Sistem Informasi}

Sistem informasi merupakan kombinasi teratur dari orang-orang, perangkat keras (hardware), perangkat lunak (software), jaringan komunikasi, dan sumber daya data yang mengumpulkan, mengubah, dan menyebarkan informasi dalam sebuah organisasi. Adapun pengertian lain sistem informasi adalah suatu sistem di dalam suatu organisasi yang mempertemukan kebutuhan pengolahan data transaksi harian, mendukung operasi, bersifat manajerial dan kegiatan strategi dari suatu organisasi serta menyediakan pihak luar tertentu dengan laporanlaporan yang diperlukan [6], [7].

\subsection{Teknik Pengumpulan Data}

Teknik pengumpulan data yang digunakan dalam melakukan pengumpulan data untuk pembuatan aplikasi perpustakaan online ini , yaitu:

a. Observasi

Mengunjungi dan melakukan pengamatan diperpustakaan pada SMK DAARUL ULUUM Jakarta yang berada di jalan karet pedurenan, setiabudi, Jakarta Selatan. untuk mengetahui kendala yang ada dan mecoba mencari solusi untuk mengatasi kendala tersebut.

b. Wawancara

Penulis melakukan proses tanya jawab dengan pengurus perpustakaan yang bernama ibu Ajeng tentang sistem yang ada diperpustakaan.

c. Studi Pustaka

Penulis menggunakan studi pustaka dengan mengambil referensi dari beberapa buku dan artikel-artikel di internet.

\subsection{Model Pengembangan Sistem}

Metode penelitian yang digunakan dalam penelitian ini adalah metode System Development Life Cycle (SDLC) dengan model Waterfall. Model air terjun (waterfall) sering juga disebut model sekuensial linier (sequential liniear) atau alur hidup klasik (classic life cycle). Model air terjun menyediakan pendekatan alur hidup perangkat lunak secara sekuensial atau terurut dimulai dari analisis, desain, pengodean, pengujian, dan tahap pendukung (support)

a. Analisis Kebutuhan 
Proses pengumpulan kebutuhan perangkat lunak yang dilakukan untuk mengetahui kebutuhan secara mendetail dalam mengembangkan sistem agar sesuai dengan kebutuhan penggunanya. analisa kebutuhan Sistem diperlukan untuk memahami dasar dari program yang akan dibuat, ruang lingkup informasi dan fungsi-fungsi yang dibutuhkan.

b. Desain dan Implementasi

Pada tahapan ini, peneliti merancang atau mendesain sesuai dengan kebutuhan, dari sisi user atau admin sebagai pengelola sistem, yaitu berfokus pada, database, serta user interface.

c. Pengkodean.

Desain harus ditranslasikan kedalam program perangkat lunak. Hasil dari tahap ini adalah program komputer sesuai dengan desain yang telah dibuat pada tahap desain. Di dalam pemecahan masalah ini digunakan teknik modular, top down dan button up. Bahasa program yang digunakan dalam pengembangan sistem informasi perpustakaan sekolah berbasis web ini adalah bahasa pemrograman PHP menggunakan basis data MYSQL dalam aplikasi XAMPP dengan mengacu pada analisis desain yang telah dibuat.

d. Testing

Tahapan pengujian yang dilakukan untuk mengetahui bahwa semua fungsi dalam sistem sudah sesuai. Pada tahapan ini peneliti menggunakan black box testing. Hal ini dilakukan untuk meminimalisir kesalahan (error) dan memastikan keluaran yang dihasilkan sesuai dengan yang diinginkan.Pengujian sistem dilakukan setelah proses penulisan kode program selesai.

\section{ANALISA DAN PEMBAHASAN}

\subsection{Prosedur Sistem Berjalan}

a. Prosedur Kunjungan Perpustakaan

Jika siswa ingin melakukan aktifitas (membaca/meminjam buku) di perpustakaan, siswa harus mengisi buku pengunjung dan menuliskan maksud dan tujuan datang ke perpustakaan. Lalu siswa mencari buku yang diperulukan. Setelah siswa selesai beraktifitas (membaca), lalu siswa mengembalikan data buku pada tempatya (katalog buku).

b. Prosedur Transaksi

Jika siswa ingin melakukan peminjaman, siswa harus mengisi data buku pengunjung, berdasarkan jurusan masing-masing. Lalu siswa mencari buku yang diperlukan. setelah siswa mendapatkan buku yang dicari, siswa menyerahkan buku tersebut kepada petugas perpustakaan. Setelah itu petugas perpustakaan mencatat data buku tersebut di buku peminjaman. Setelah selesai pencatatan buku diserahkan kepada siswa. Pada proses pengembalian siswa harus mengembalikan buku kepada petugas perpustakaan dan mengisi data pengembalian pada buku pengembalian, jika siswa terlambat mengembalika buku selama lebih dari 3 hari dikenakan denda perhari Rp 2000.

c. Prosedur Laporan

Petugas perpustakaan membuat laporan data pengunjung setiap bulanya berdasarkan buku pengunjung. Petugas perpustakaan membuat laporan data peminjam setiap bulanya berdasarkan buku peminjam. Petugas perpustakaan membuat laporan data pengembalian setiap bulanya berdasarkan buku pengembalian. Dan semua laporan di setujui oleh kepala perpustakaan, dan akan di serahkan ke kepala sekolahh lalu di arsipkan.

\subsection{Analisa Kebutuhan}

Dalam aplikasi sistem informasi perpustakaan berbasis website ini terdapat dua pengguna yang saling berinteraksi yaitu admin perpustakaan dan anggota perpustakaan. Kedua pengguna tersebut memiliki karakteristik interaksi dengan sistem yang berbeda-beda dan memiliki kebutuhan informasi yang berbeda-beda, seperti berikut :

Kebutuhan Pengguna :

a. Skenario Kebutuhan Admin:

1) Admin dapat mengelola data buku.

2) Admin dapat mengelola data admin.

3) Admin dapat mengelola data anggota.

4) Admin dapat mengelola katalog buku.

5) Admin dapat mengelola data peminjaman.

6) Admin dapat mengelola data pengembalianAdmin dapat membuat laporan.

b. Skenario Kebutuhan Anggota:

1) Penggunjung dapat melakukan registrasi menjadi anggota perpustakaan.

2) Anggota dapat mencetak kartu anggota.

3) Anggota dapat melakukan update data pribadi anggota.

4) Anggota dapat melihat katalog buku.

5) Anggota dapat melihat informasi data peminjaman. 
Kebutuhan Sistem

a. Pengguna harus login untuk bisa menggunakan aplikasi ini secara maksimal, dan dapat mengelola akun dan data nya.

b. Pengguna harus logout setelah selesai menggunakan aplikasi ini.

c. Sistem melakukan kalkulasi buku yang tersedia.

\subsection{Use Case Diagram}

Terdapat 2 aktor pada aplikasi perpustakaan online, yaitu admin dan anggota, dimana actor akan melakukan login terlebih dahulu di dalam system, lalu anggota mengisi buku tamu dan bisa mencari buku yang diinginkan dalam aplikasi perpustakaan online.

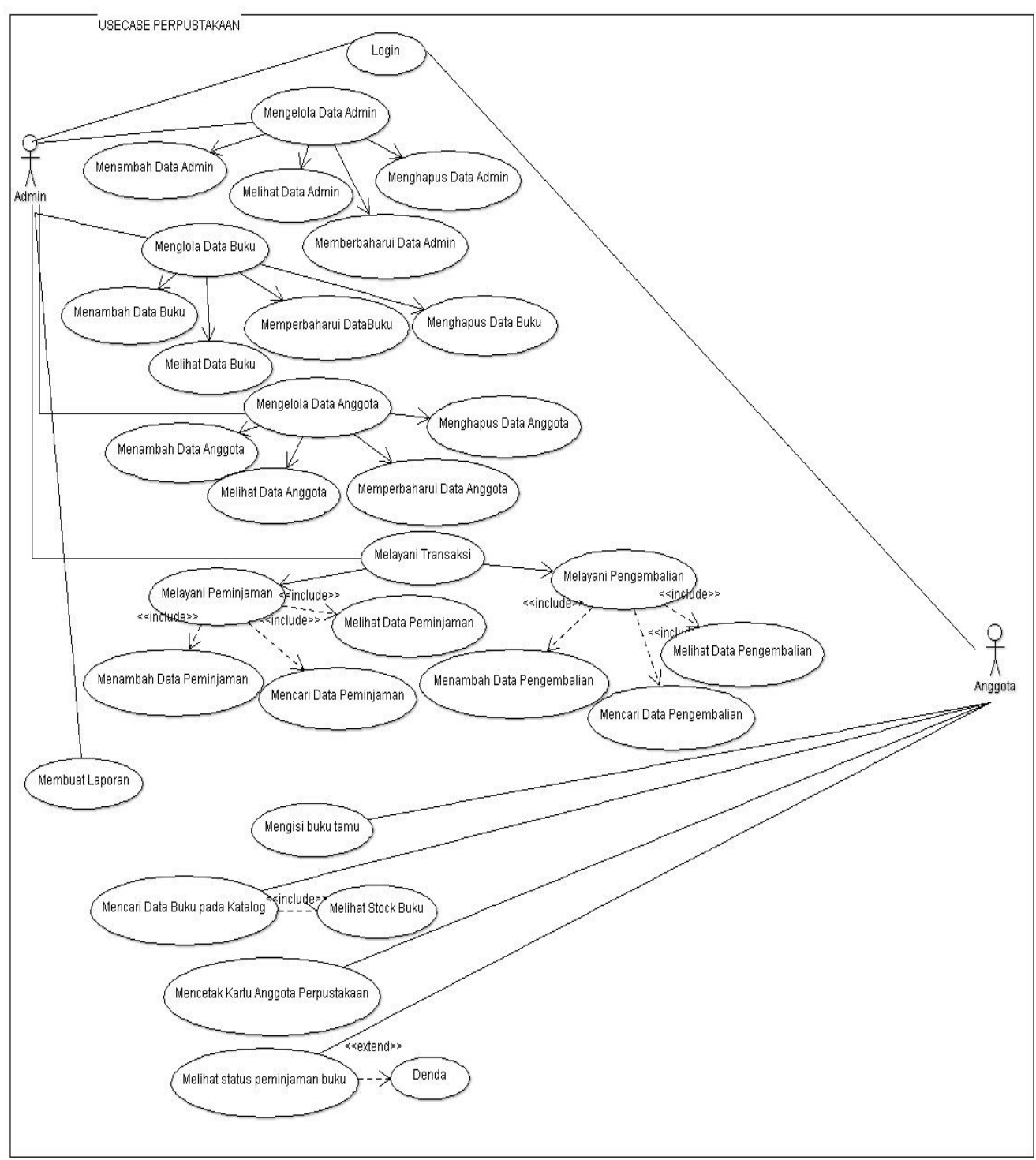

Gambar 1. Diagram Use Case

Tabel 1. Deskripsi Use Case Peminjaman buku

\begin{tabular}{|l|l|}
\hline Use case name & Peminjaman buku \\
\hline Requirements & Anggota dapat melihat katalog buku \\
\hline Goal & Anggota dapat melihat katalog buku melalui website \\
\hline Pre-Conditions & Anggota tidak login \\
\hline Post-Conditions & Siswa belum menjadi anggota perpustakaan \\
\hline Failed end Condition & Tidak dapat melakukan peminjaman buku \\
\hline Actors & Anggota \\
\hline Main Flow/ Basic Path & 1. Siswa melakukan registrasi menjadi anggota perpustakaan. \\
& 2. Anggota melakukan login. \\
& 3. Anggota mencari buku yang di perlukan pada katalog buku. \\
\hline
\end{tabular}




\begin{tabular}{|c|c|}
\hline Use case name & Peminjaman buku \\
\hline & 4. Jika buku tersedia, anggota dapat meminjam buku. \\
\hline Alternate Flow/Invariant A & $\begin{array}{l}\text { 1. Sistem menampilkan data buku yang tersedia. } \\
\text { 2. Anggota dapat meminjam buku yang tersedia. }\end{array}$ \\
\hline Invariant $\mathrm{B}$ & $\begin{array}{l}\text { 1. Anggota melakukan pencarian buku perjurusan. } \\
\text { 2. Anggota mengetikan judul buku. } \\
\text { 3. Sistem gagal menemukan buku yang di cari. } \\
\text { 4. Sistem meampilkan pesan buku yang anda cari tidak di temukan. }\end{array}$ \\
\hline
\end{tabular}

\subsection{Rancangan Diagram Aktivitas}

\section{a. Activity diagram Peminjaman Buku}

Pada activity diagram terdapat 3 aktor yaitu anggota, system dan admin. Activity diagram dibuat berdasarkan sebuah atau beberapa use case. Menggambarkan proses bisnis dan urutan aktivitas dalam sebuah proses.

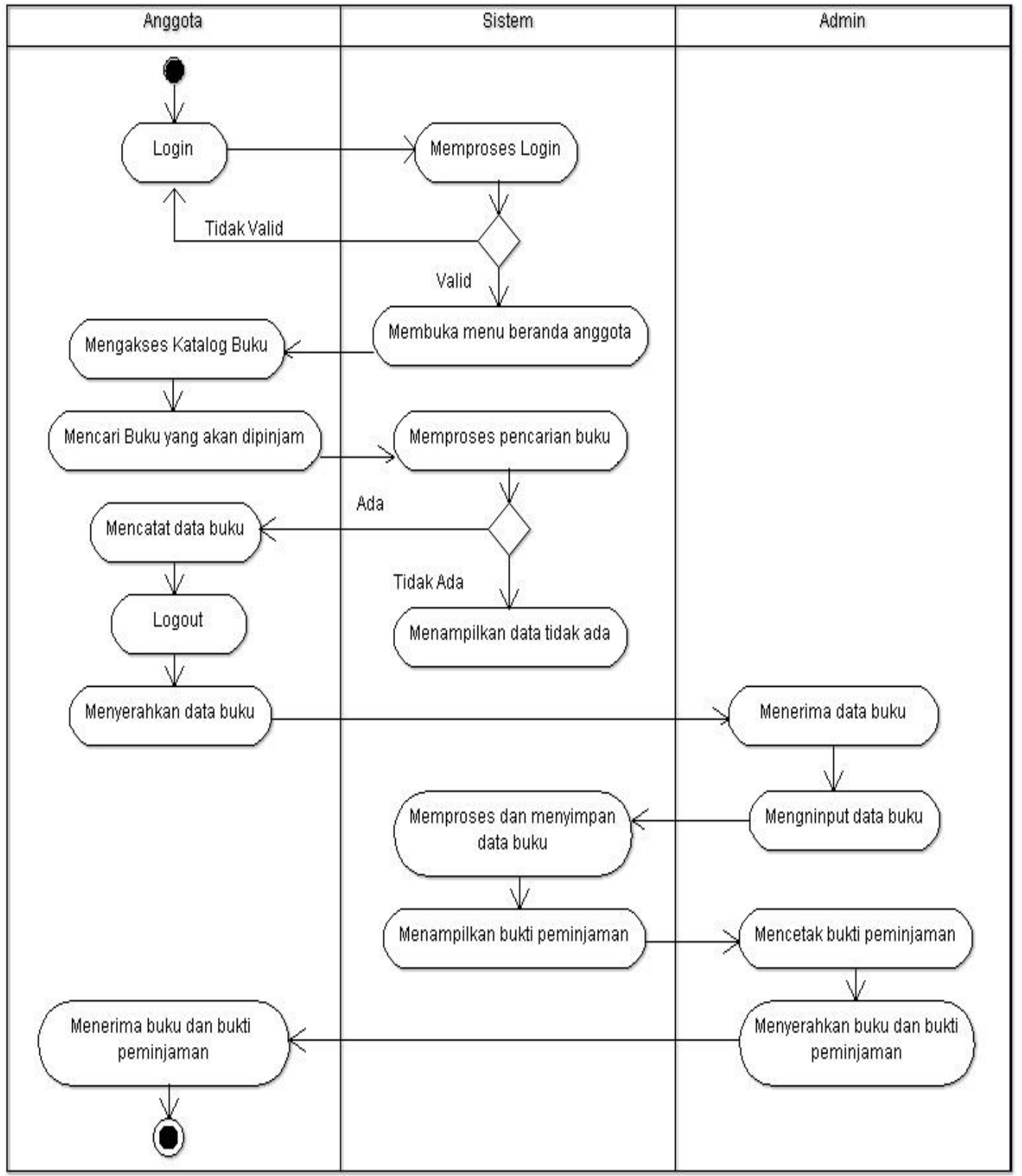

Gambar 2. Diagram Aktivitas Peminjaman Buku

\section{b. Activity diagram Pengembalian Buku}

Di sini di jelaskan urutan aktivitas pengembalian buku yang terdiri dari 3 aktor yaitu anggota, system dan admin. Dimana anggota melakuan pengembalian buku kepada admin dan akan dimasukan ke dalam system aplikasi perpustakaan online. 


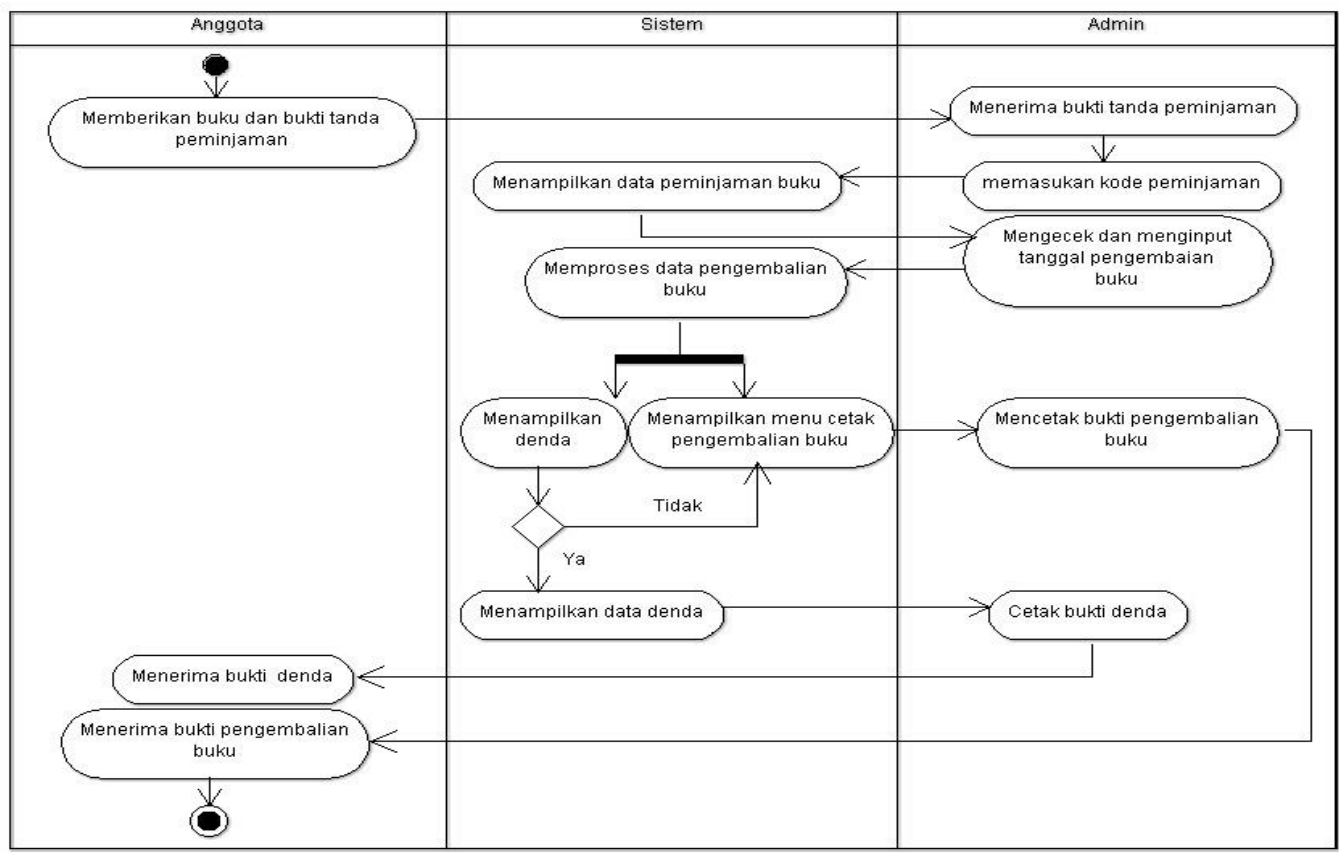

\subsection{Sequence Diagram}

Gambar 3. Diagram Aktivitas Pengembalian Buku

\section{a. Sequence Peminjaman Buku}

Di dalam sequence diagram peminjaman buku terdiri dari actor anggota dan admin, menu katalog dan transaksi peminjaman sebagai boundary class, proses peminjaman sebagai control class, dan cetak bukti peminjaman sebagai entity.

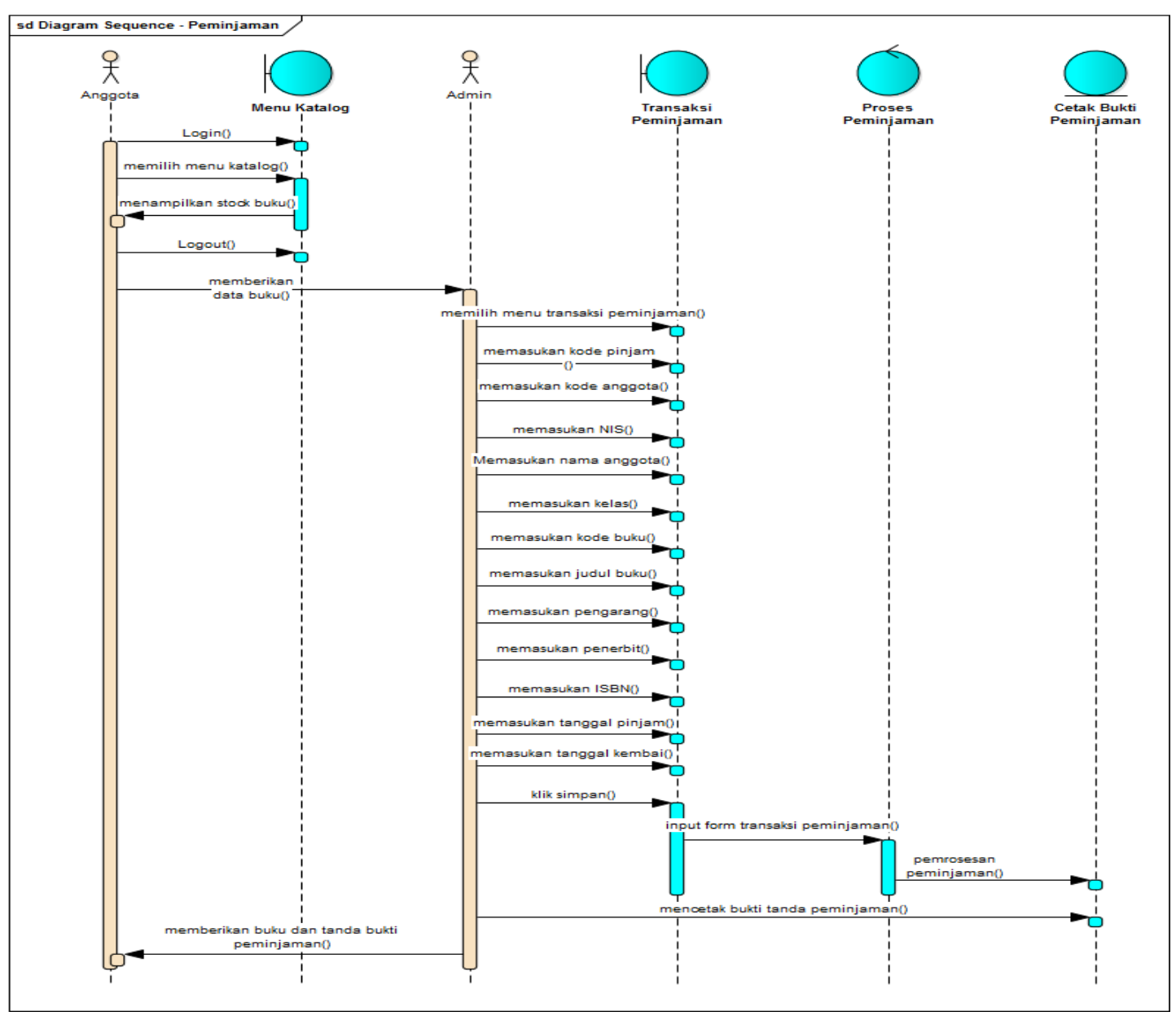

Gambar 4. Diagram Sequence Peminjaman Buku 


\section{b. Sequence Pengembalian Buku}

Di dalam sequence diagram pengembalian buku terdapat actor anggota dan admin, boundary calss terdiri dari form data master pengembalian dan tabel data pengembalian, proses pengembalian buku sebagai control class dan cetak bukti pengembalian sebagai entity class

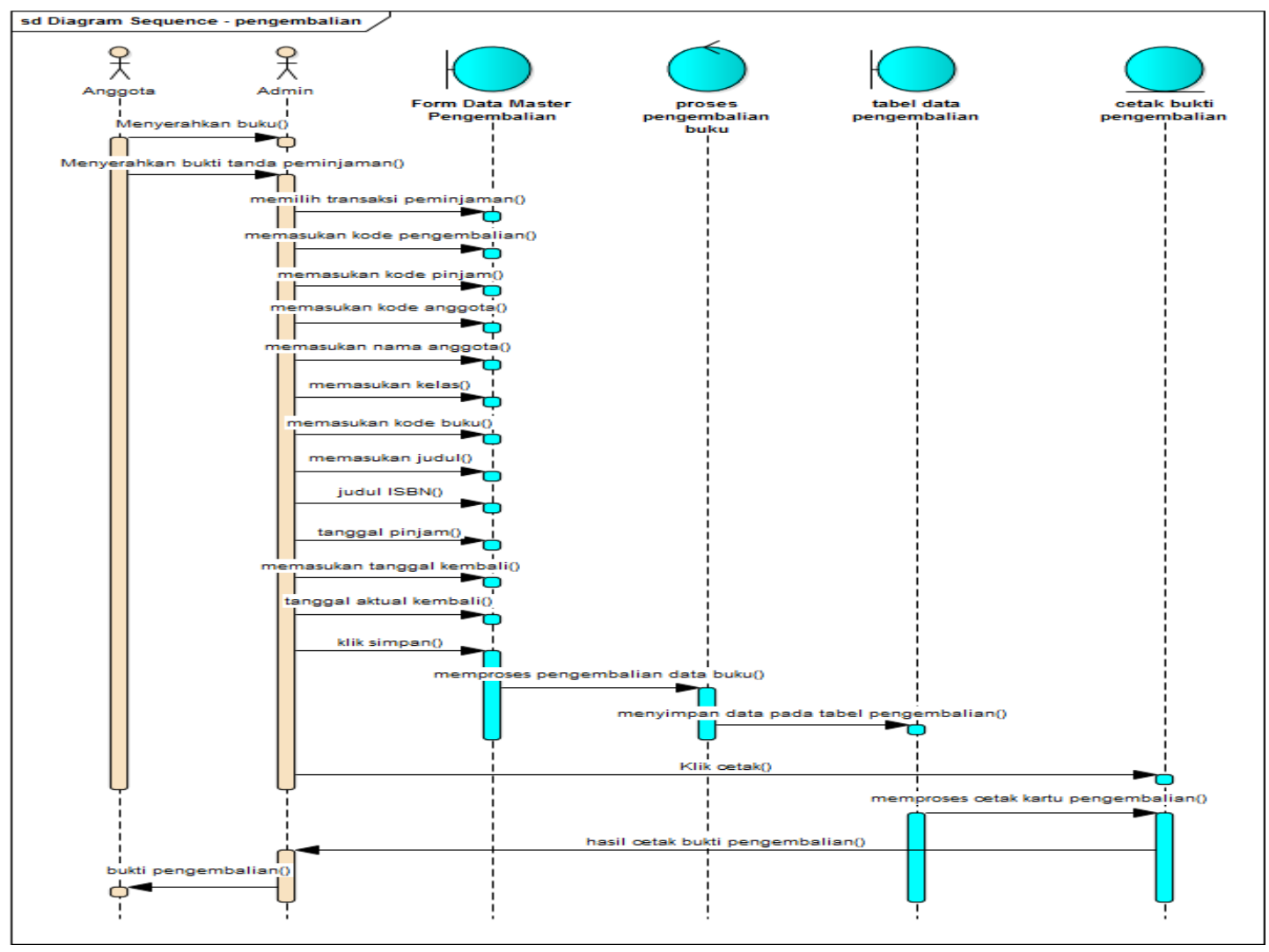

Gambar 5. Diagram Sequence Pengembalian Buku

\subsection{Class Model / Class Diagram}

Dibawah ini adalah class diagram aplikasi perpustakaan online yang terdiri dari beberapa class,, yaitu class admin, class pengembalian, class buku, class peminjaman, dan class anggota. Class-class tersebut memiliki atribut dan metode (operasi).

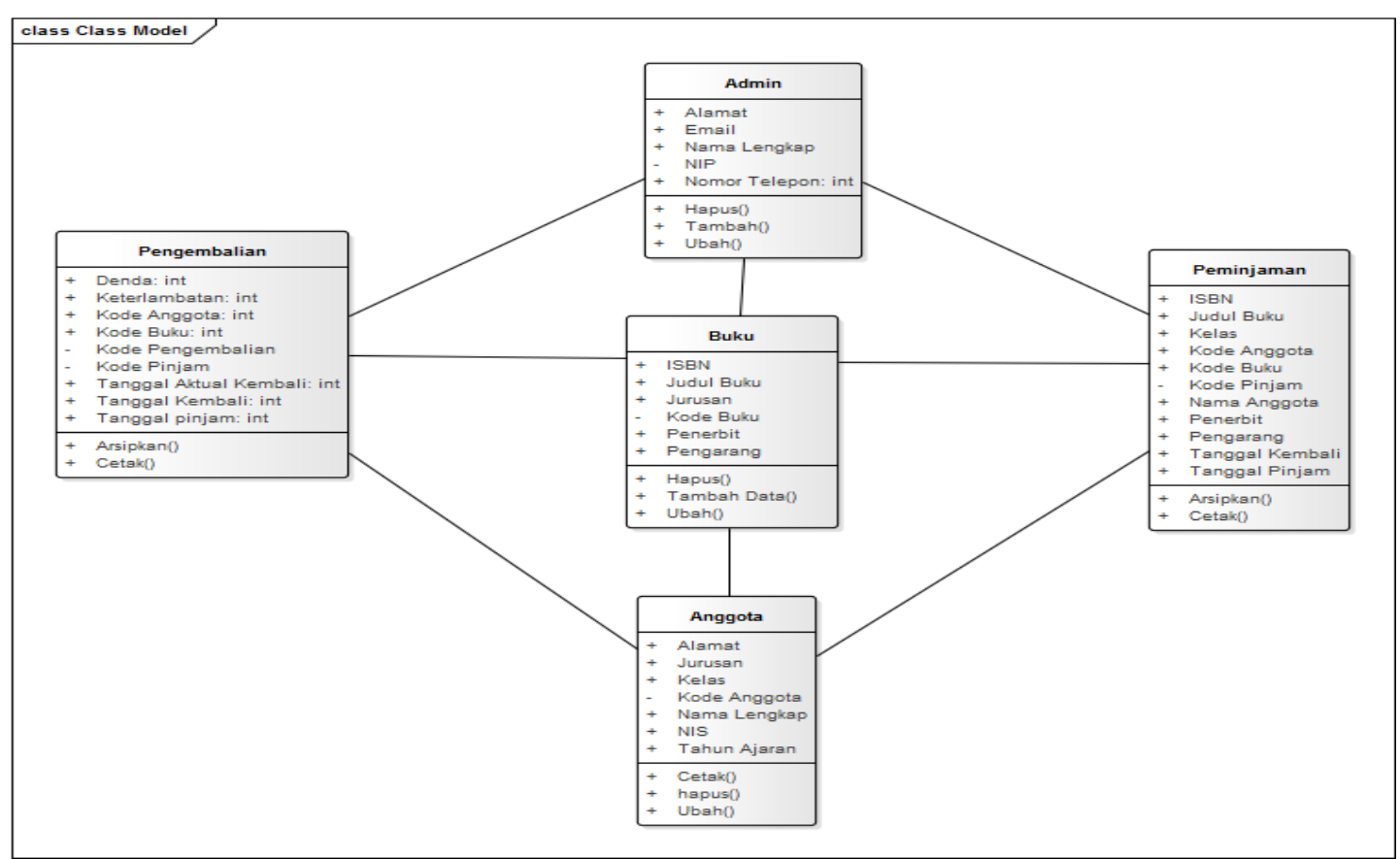

Gambar 6. Class Model / Class Diagram 
Building of Informatics, Technology and Science (BITS)

Volume 2, No 2, December 2020 Page 165-175

ISSN 2684-8910 (media cetak)

ISSN 2685-3310 (media online)

\subsection{Entity Relationship Diagram}

Perancangan basis data sistem informasi perpustakaan online menghasilkan pemetaan tabel-tabel yang digambarkan dengan Entity Relationship Diagram (ERD) sebagai berikut:

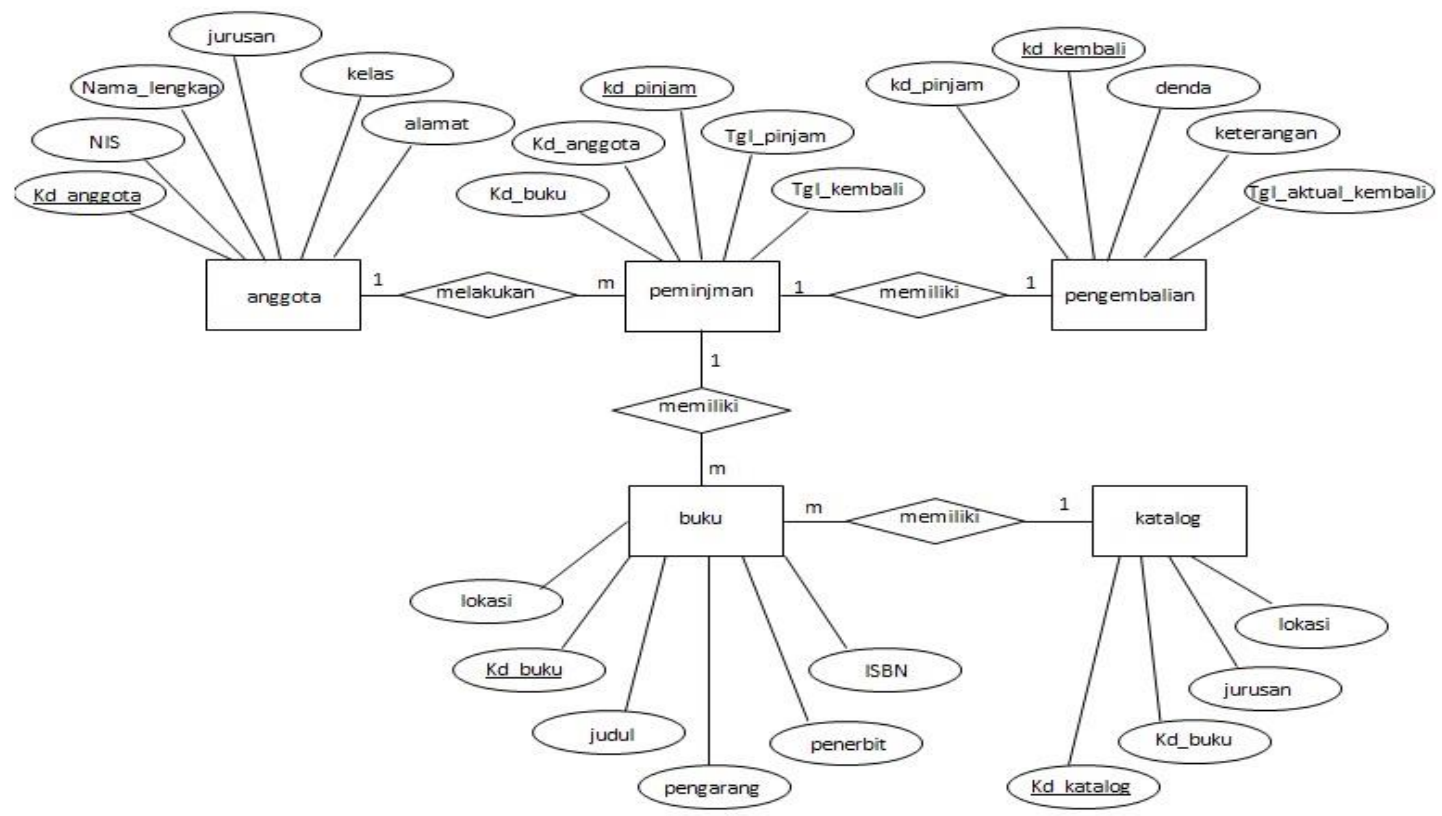

Gambar 7. Entity Relationship Diagram

\subsection{Logical Record Structure}

Setelah menggambarkan ER-Diagram, selanjutnya kita akan mentransfomasi ER-Diagram tersebut ke Logical Record Structure (LRS).

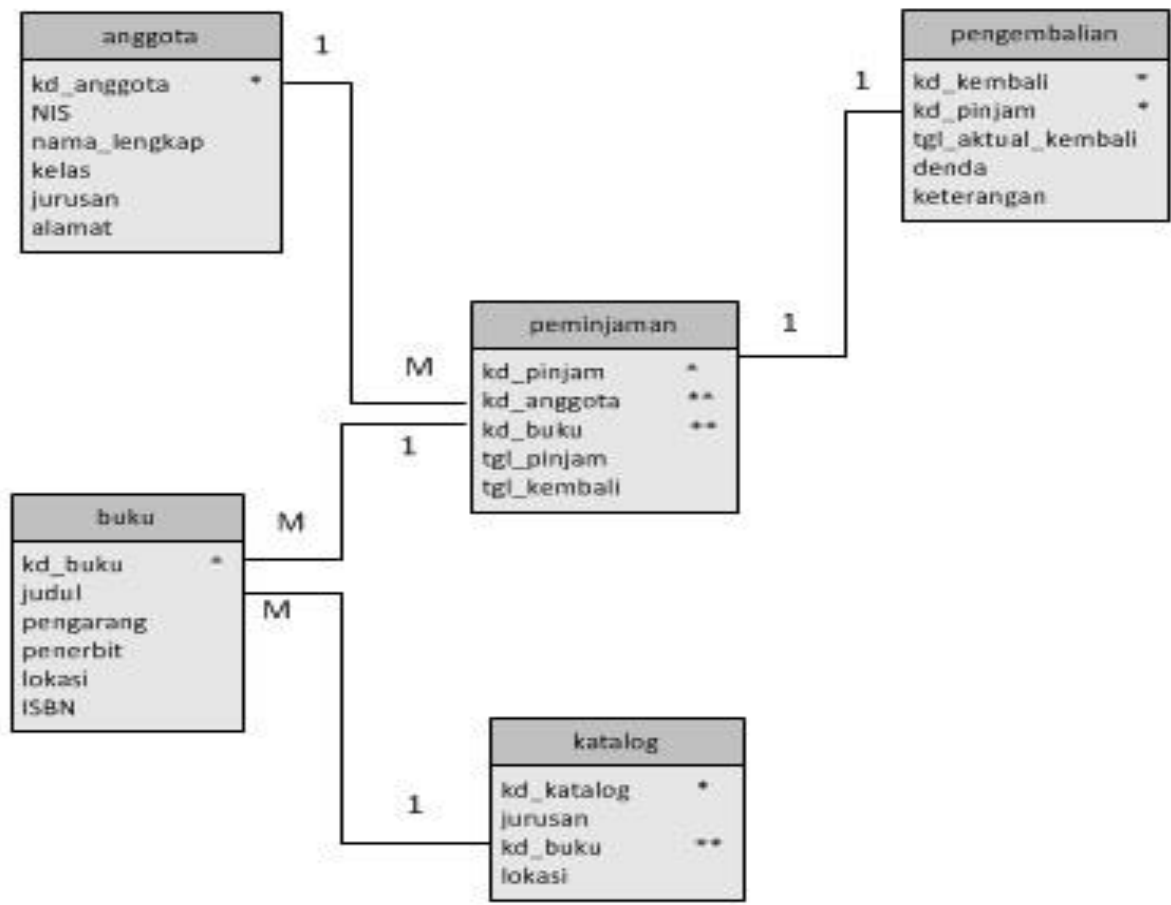

Gambar 8. Logical Record Structure (LRS)

\subsection{Implementasi Program}

1. Halaman Utama Pengunjung

Merupakan halaman bagi pengunjung yang akan memulai melakukan pencarian atau peminjaman buku 


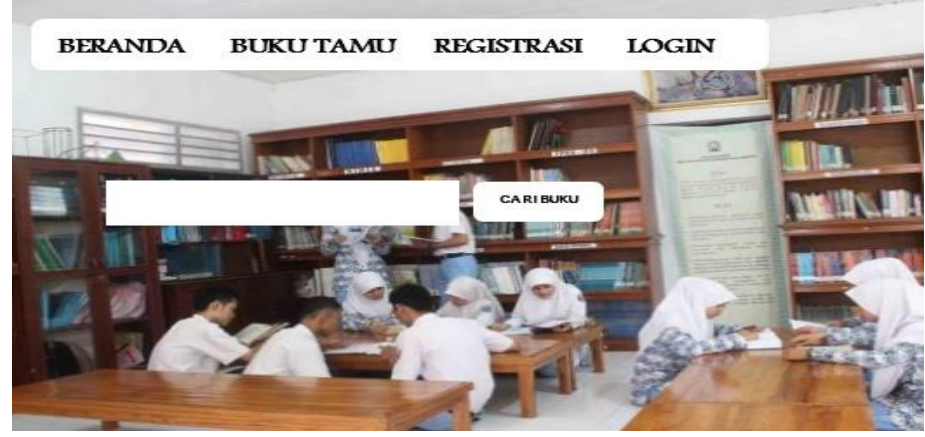

Gambar 9. Halaman Utama

2. Halaman isi formulir pengunjung

Halaman dimana siswa mengisi keperluan di dalam perpustakaan online

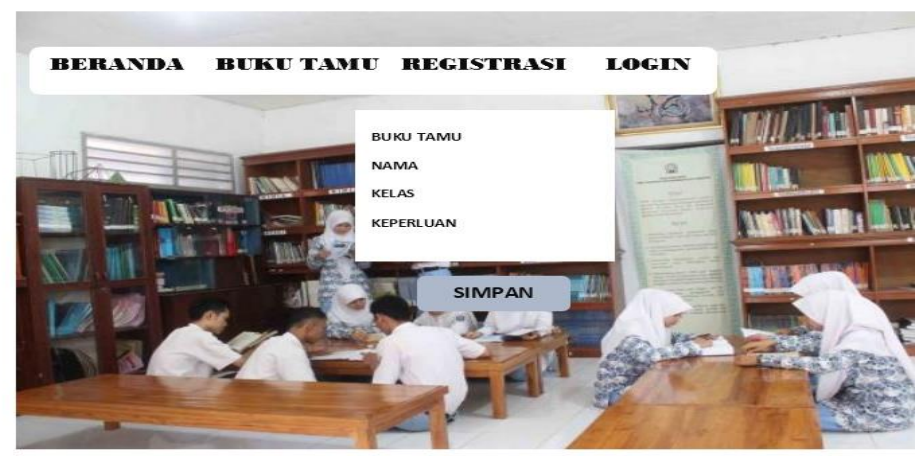

Gambar 10. form pengunjung (siswa)

\section{Halaman Katalog}

Halaman dimana siswa bisa mencari buku yang akan di pinjam

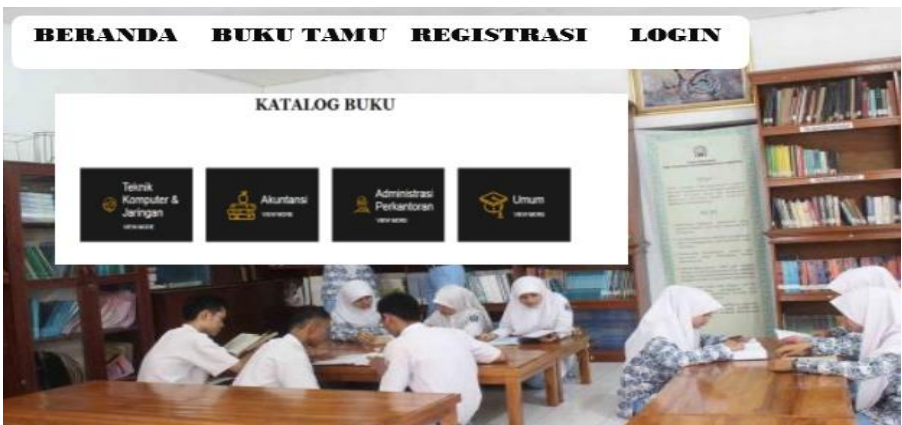

Gambar 11. Halaman Katalog Buku

\section{Halaman Pendaftaran Anggota}

Bagi siswa yang ingin melakukan peminjaman bisa melakukan pendaftaran di halaman registrasi

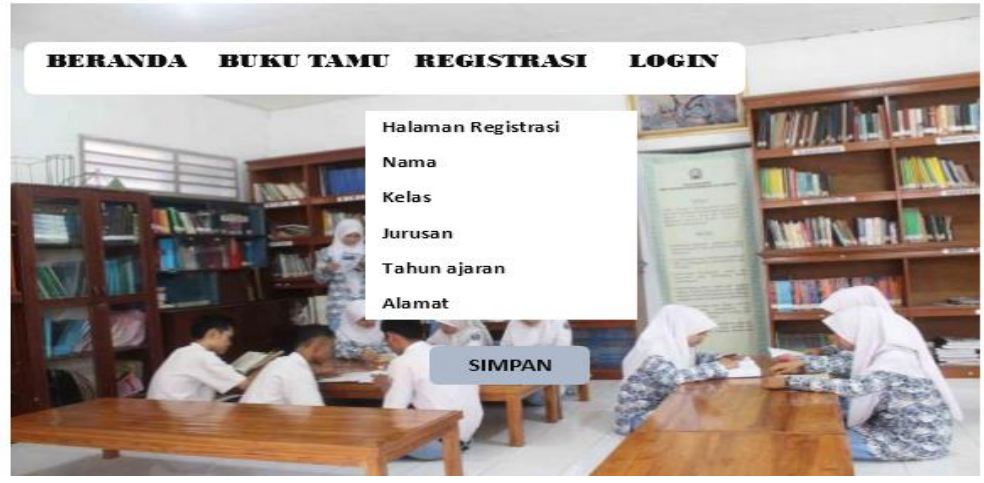

Gambar 12. Halaman Pendaftaran Anggota 


\section{Halaman Beranda jika sudah login anggota}

Halaman untuk login anggota yang sudah registrasi

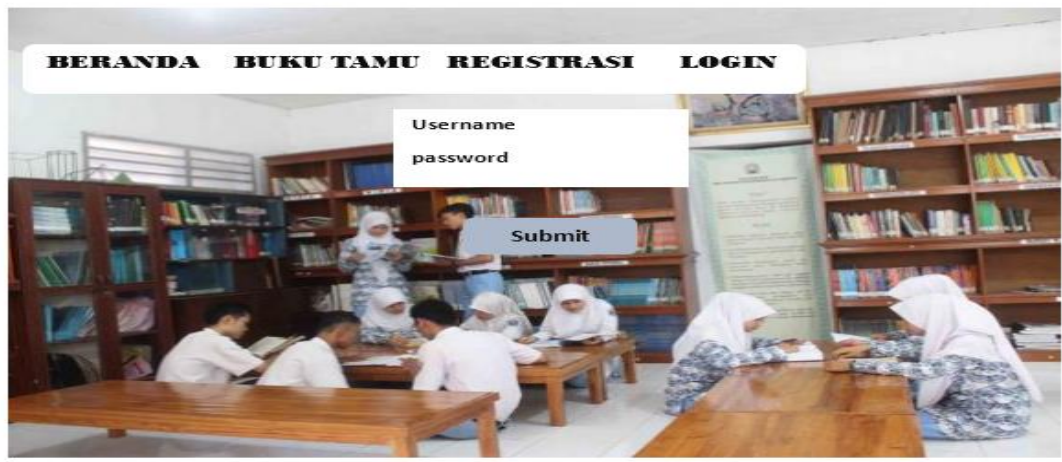

Gambar 13. Halaman Login Anggota

\section{Halaman Kartu Anggota}

Halaman untuk mencetak kartu anggota perpustakaan

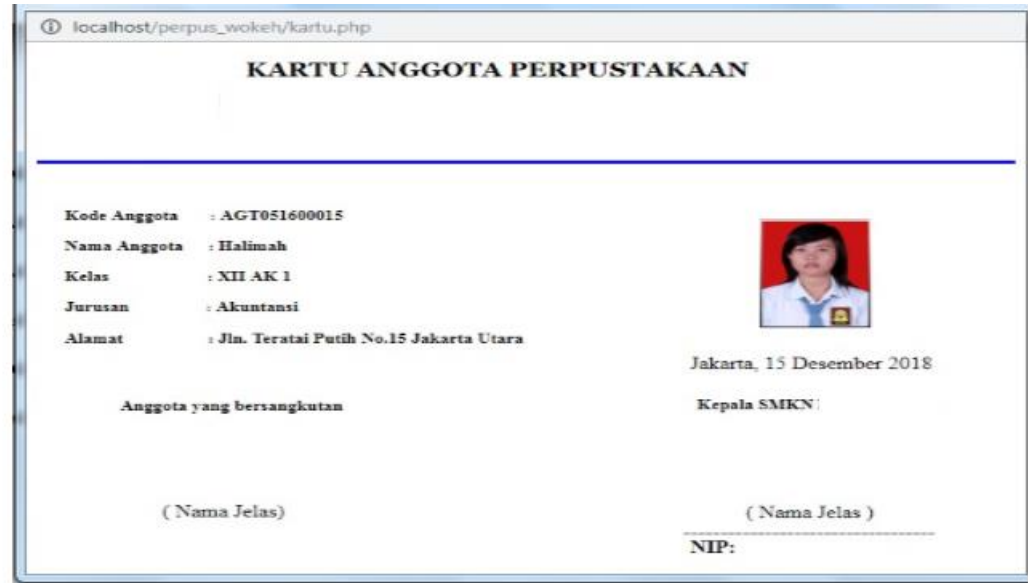

Gambar 14. Halaman cetak kartu anggota

\section{Halaman Katalog}

Halaman admin untuk mengolah data-data buku

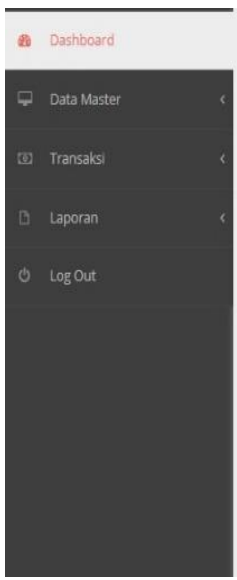

\section{Data Master Katalog}

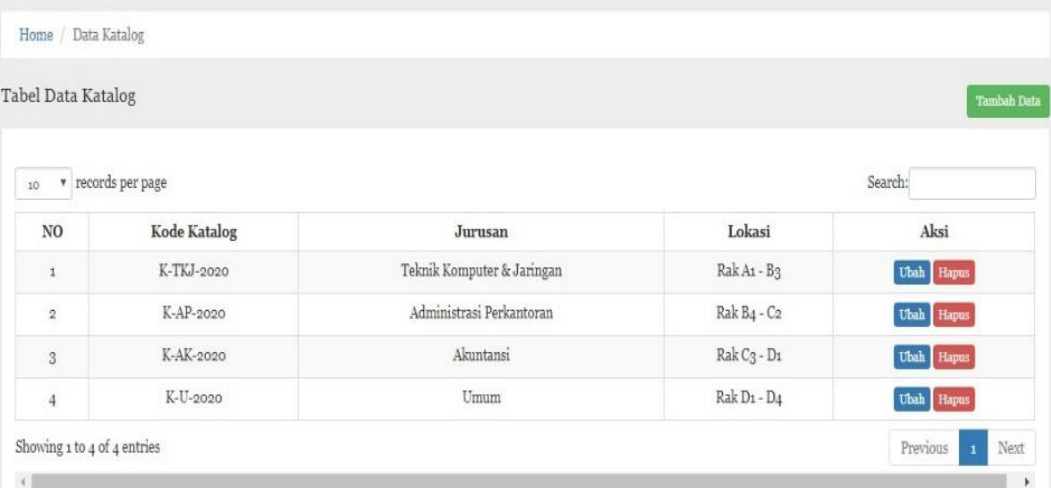

Gambar 15. Halaman katalog buku untuk admin

8. Halaman Laporan

Di halaman ini terdapat laporan data peminjaman dan pengembalian buku 


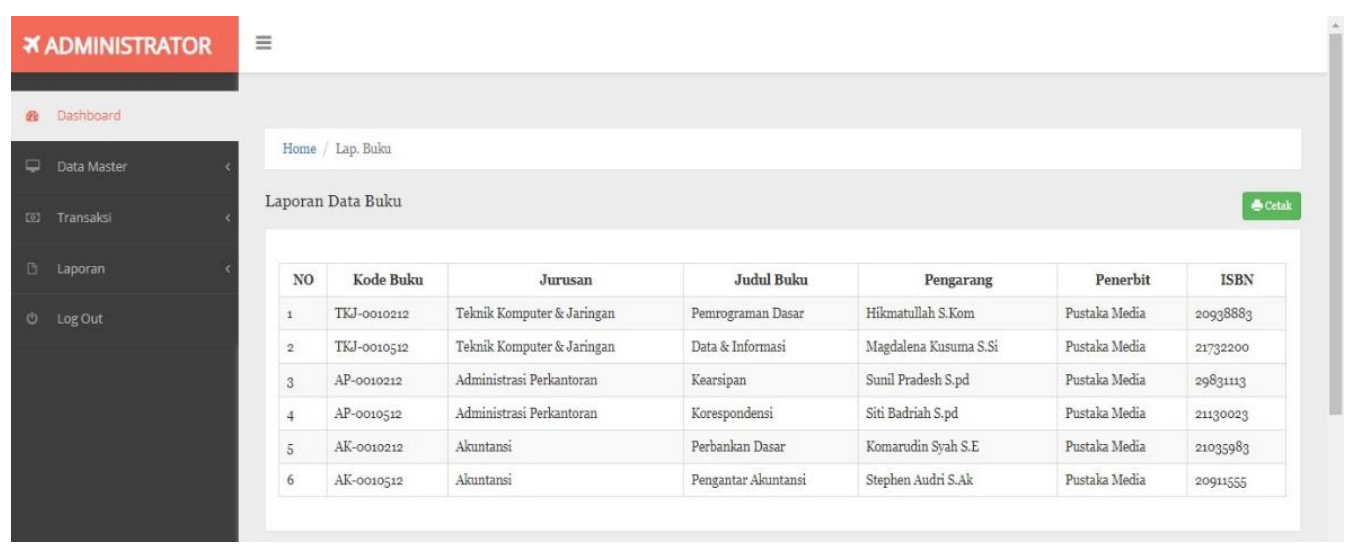

Gambar 16. Halaman laporan data peminjaman

\section{KESIMPULAN}

Kesimpulan dari implementasi perpustakaan online ini adalah untuk memudahkan siswa dan staff admin perpustakaan dalan hal mencari buku, melakukan pendataan buku dan mengelola buku. Aplikasi perpustakaan dapat membantu kegiatan pendaftaran dan transaksi peminjaman dan pengembalian serta denda di perpustakaan sehingga proses pendaftaran dan transaksi lebih cepat. Aplikasi perpustakaan yang di bangun di dukung oleh fasilitas katalog sehingga informasi mengenai buku yang di butuhkan oleh anggota mudah di dapat, sehingga cepat dan akurat.

\section{REFERENCES}

[1] M. Al and M. Pekayon, “SISTEM INFORMASI PERPUSTAKAAN ONLINE ( E-LIBRARY ) PADA,” vol. 4, no. 2, pp. 245-250, 2019.

[2] J. Simarmata, Pengenalan Teknologi Komputer dan Informasi. Yogyakarta: Andi, 2006.

[3] K. Fahmi, A. T. Haryono, I. F. Astuti, and D. Cahyadi, "BERBASIS MULTITENANT," vol. 11, no. 1, 2016.

[4] S. N. Arif, A. P. Wanda, and A. Masudi, "APLIKASI ADMINISTRASI PERPUSTAKAAN BERBASIS WEB SMK SWASTA BRIGJEND KATAMSO MEDAN,” pp. 25-36, 1978.

[5] D. E. Hendrianto, "Pembuatan Sistem Informasi Perpustakaan Berbasis Website Pada Sekolah Menegah Pertama Negeri 1 Donorojo Kabupaten Pacitan," vol. 3, no. 4, pp. 57-64, 2014.

[6] A. D. Firman, "Sistem Informasi Perpustakaan Online Berbasis Web," J. Tek. Elektro dan Komput., vol. 5, no. 2, pp. 29-36, 2016.

[7] J. Hutahaean, Konsep Sistem Informasi. Deepublish, 2018. 